\title{
SNAI2 wt Allele
}

National Cancer Institute

\section{Source}

National Cancer Institute. SNAI2 wt Allele. NCI Thesaurus. Code C52105.

Human SNAI2 wild-type allele is located in the vicinity of $8 q 11$ and is approximately $4 \mathrm{~kb}$ in length. This allele, which encodes zinc finger protein SNAI2, is involved in the repression of both transcription and apoptosis. Mutations in this allele cause neural tube defects and Waardenburg syndrome types. 